\title{
A Review of Drama Education (UK) and Integral Drama Based Pedagogy (China), Western and Eastern Perspectives and Influences
}

\author{
Clive HOLMWOOD \\ Dr., Associate Professor, Discipline of Therapeutic Arts, School of Arts, \\ College of Arts, Humanities \& Education, University of Derby, Derbyshire, \\ UK \\ c.holmwood@derby.ac.uk
}

\begin{abstract}
This article will consider similarities to and connections with western progressive based drama education and recent developments in China, namely Integral Drama Based Pedagogy (IDBP). It will also consider links between dramatherapy and IDв which considers drama from a more emotional and integral education perspective. It will begin by giving a brief history of drama and progressive education in the UK followed by the development of integral education in general and then make connections between the training of dramatherapists in the west to that of student of IDBP.
\end{abstract}

\section{Keywords}

drama education - dramatherapy - integral education - integral drama based pedagogy

\section{Introduction}

This article will consider the connections between western (UK) based pedagogical progressive drama education (Cook 1917, Slade 1954, Bolton 1988), creative learning in higher education, in arts in health and arts therapies (Taylor \& Holmwood, 2019) and the newly developing ideas around Integral Drama 
Based Pedagogy (IDBP), currently being developed by Ma. It has clear connections with my own research (Holmwood, 2014) which considered the liminal space between education and therapy.

IDBP is an approach being developed in Chinese Universities based mostly on the work of renowned educational theorists; from China, the Neo-Confucian ideas of Wang Yang-Ming (Ching 1976), and from India, the influential work of Sri Aurobindo and Mirra Alfassa, known as the 'The Mother,' who argued for educational approaches that harmonised physical and mental health within an educational context. Likewise with my own work (Holmwood, 2014) challenging the binary assumption that education is neither one thing or another, I argue that educational drama can be therapeutic, and therapy can be educational.

I begin this debate by acknowledging that it can be problematic comparing Western and Eastern educational philosophies and recognising my own positioning and prejudices in relation to this. I have discussed elsewhere that 'there is usually an inherent (academic) tension when making connections between two ideas which on the surface have few similarities and very different philosophies' (Holmwood, 2015, p. 65). It could be argued that Western and Eastern educational philosophies share limited roots or connections due to hundreds if not thousands of years of cultural, social, spiritual, political and philosophical separation. However, if we examine this more closely there might be unspoken connections worthy of consideration

Previously I have examined the similarities and differences between two connected disciplines, drama education and dramathrapy and found inherent tensions between these two western based disciplines (Holmwood, 2014). It is just as challenging when education as a broad construct is considered from two dialectical opposed cultures, which could be described as a liberal West verses a Confucian orientated East. When I say 'Confucian' I mean the broad Confucian notion of harmony, order and discipline. When I use the world 'liberal' I mean that generally Western cultures are based on the notion of 'democracy,' and a free market economy. I use the words 'liberal' and 'Confucian' here not to cause tension but to acknowledge the unsaid differences, so that the debate can be as open as possible and laid out for us to consider. Hiding from these tensions or pretending they do not exist is neither helpful nor constructive.

Secondly, I must acknowledge my own prejudices. I am a product of a Western based $\left(\right.$ liberal $\left.^{1}\right)$ approach to education. This is something I cannot

1 When I say liberal, I refer to democracy and free market economy. I do not personally feel that education in the UK over the last 30 years has been particularly liberal, especially with the developments in primary and secondary education. 
escape. I am imbued within this philosophical upbringing but was possibly at the fading vanguard of the progressive educational movement in the UK which has slowly dissipated since the 1970's and has become more of an exam orientated process in education in primary and secondary schools, where exam attainment and league tables take centre stage. This is now commonly described both in law and in educational terms in the UK as the 'National Curriculum. ${ }^{2}$ Which means all state schools offer an almost identical curriculum at all stages of primary and secondary education. Academy schools, schools run not by local authorities but on behalf of the government by private companies, are free from the National Curriculum, but not free from standardised assessments.

Dewey (1938) has described this notion of educational progressivism as being ' marked by the opposition between the idea that education is development from within and that it is a formation from without' $(1938$, p. 1$)$ He further states ' it is a process of overcoming natural inclination and substituting in its place habits acquired under external pressure' (1938, p.1). In other words, progressive approaches start within and reach out. Whereas 'Traditional Approaches refer to acquiring knowledge through rote learning and sitting formal examinations to prove one's knowledge' (Holmwood, 2014, p. 5). Traditional approaches start outside and reach in. It could be argued that a Western by product of good education' is economic generation, everyone having the same knowledge to carry out future work in the same way. Whereas more progressive approaches lie less on rote learning (outside in) and the acquisition of and understanding of ideas, but on individual learning through experience (inside out). Thus, making education relational and giving greater meaning to each individual and the way they use it in the future. So early on we see that progressive approaches are about internal embodied experiences in the first place that connect out to the external world and others.

According to Howlett (2014) ideas around progressive education can be charted back throughout history, though he describes Rousseau's Emile (1762) as being 'the first explicitly 'progressive' educational work' (2014, p. 30). Emile is a fictionalised story that charts the relationship and education of Emile with his tutor. The very first of its kind. Howlett described that with its publication 'a seismic shift in the educational paradigm took place' (2014 p. 3). Rousseau

2 https://www.gov.uk/government/collections/national-curriculum Accessed 27.10.20. 
could be described as coming from a more 'romantic' movement in which there was greater concern about the natural development of the child, rather than an adult imposed curriculum. Thus suggesting the relational nature of education.

Howlett further discusses that the 2oth Century was the 'American Century' (p. 177) in relation to progressive education. Howlett described Dewey as being uncomfortable about the 'industrialisation' of education, in a world in which education was there just to prepare someone for a mechanised industrial life and that education in its developing form represented that new 'industrial age'. Howlett goes on to imply that in Dewey's view 'school was not merely seen as preparation for life but that it was a representation of life itself' (Howlett, 2014, p. 187). In other words, school was not about telling you how to do something mechanistically, in a particular way, but was about allowing each student to find their own way to carry out a task based on intuition and trial and error. ${ }^{3}$

Representation is a central element to drama, when we represent something, or take on the role, we get inside the skin of the character, so we can see things from that position, we embody it. This is a key ingredient in educational drama. It could be argued that early drama education in the UK was developing along these progressive lines that Dewey was outlining. Especially when more mainstream approaches incorporated the needs for mass education of all children to prepare them for the new industrial age and with that the new industrial revolution that was to come.

Caldwell Cook one of the earliest drama educationalists in the UK, a teacher and headmaster in his unique book 'The Play Way' (Cook, 1917), described an approach to education he had seen develop during the first world War. He felt that historically the 'classroom (had been) stuffier than ever, the autocracy of the pedant more unbearable, the process of spoon feeding more repugnant' (Cook, 1917: vii). Cook believed that the 'natural means of study in youth is play .... A natural education is by practice, by doing things, and not by instruction' (2017, p. 1). Again, this rekindles this notion of an internalised, embodied education, feeling and doing rather than just thinking. The notion of rote learning, of learning by repetition, when the repetition itself became meaningless was an anathema to Cook. It could be argued that Cook's notion of learning through play echoed Howlett's view that Dewey saw education as not being a preparation for life but a representation of life. Cook saw the classroom not as a place where instructions were given but as a place of 'play', the classroom

3 Dewey had some considerable impact on Chinese education having spent some 26 months in China starting in 1919 (Peters 2019) delivering many lectures. China was at a turning point where it needed to consider what kind of education it wanted. 
was a place of experimentation. However, this did not mean that there was not discipline, as Cook states 'the play method sets order, and systemic discipline' $(1917$, p. 51) within the classroom, whilst the teacher plays the role of the 'play master'.

Educationalist, drama teacher and founding UK dramatherapist Peter Slade was born in 1912, just before World War 1, at the same time Cook was experimenting and beginning to question and challenge the validity of an age-old formal rote educational system. Slade's seminal work 'Child Drama' (1954) purported this notion of 'play' as being central to a child's educational development and he took this further throughout his teaching and educational career. His work too took a further step forward; Cook's work was at a highly prized public school, Slade worked with troubled youth in inner city schools. Specifically, much of his work was within the Rea Street Centre in inner City Birmingham, UK, where he saw the emotional, psychological and social difficulties many deprived working class children had developed (Slade, 1995).

He had a major influence upon not only UK progressive drama educational approaches but on the creation and development of dramatherapy. Slade was the first to link this notion of drama as having both educative and therapeutic potential. As early as 1940 in a lecture to 'The Guild of Pastoral Psychology', Slade discussed 'The Value of Drama in Religion, Education and therapy'. Though he did not coin the phrase dramatherapy (UK spelling - one word) until a later Guild lecture in 1958 entitled Dramatherapy as an Aid to Becoming a Person (Slade, 1958). By this stage he had realised the notion of drama as being a way of aiding the whole person, emotionally, educationally, and therapeutically. Slade was particularly interested in movement and embodied approaches to working with children, which will be highly relevant when we discuss some of the principals of integral education later. He later had connections with the two key figures who developed dramatherapy in the UK, Billie Lindkvist, for whom Slade was on the Board of the Sesame Association (Lindkvist, 1998) (a particular dramatherapy approach that relies more on embodied movement approaches), for many years; and Sue Jennings at the Remedial Drama Centre (where she worked with disabled children in the early years of the development of dramatherapy), (Jennings, 1984).

Other very influential drama educators such as Dorothy Heathcote (O'Neil and Johhson, 1984) and Gavin Bolton (1988) developed similar progressive approaches to drama education. Heathcote in particular developed what was to be famously known as 'The Mantle of the Expert' 'where the class is set up in such a way that they function as experts' (O'Neill, 1984, p. 205) The students took on the role of the characters and became experts in finding out what the 
problem was and how to solve it. However, these innovators, it could be argued sadly had limited impact on how drama was seen in mainstream primary and secondary education. As Bolton writes in 1988 when writing about Slade and another one of the early drama innovators Brian Way, he states that neither of them (Slade or Way) 'had very much impact on what drama meant and still means to interested people outside of our educational institutions' (Bolton 1988 , p. 6o) In other words, to many, drama was seen as nothing more than the performance of a school play at the end of term.

Creativity, Arts \& Drama \& Arts Therapies in Higher Education in the UK

Controversially, I suggest, the role of the 'arts' in Higher Education in the UK largely shares a similar fate, though some may disagree. Though there is an arts base in Higher Education, much of it, it could be argued, is discipline specific, there to train artists, actors, musicians, and dancers. There is of course absolutely nothing wrong with this. We need actors, musicians, and artists to fuel our creative industries. However, in just the same way that historically primary and secondary education prepared people for work in an industrialised age, Higher Education, which is no longer free or cheap, ${ }^{4}$ to an extent sees its role as to prepare individuals for their graduate position and accompanying salary. Though even now 'artists' are not necessarily classed as being in a 'graduate' profession as defined by 'Universities Destination of Leavers' data. ${ }^{5}$

Hogan (2001) has charted the development of Art Therapy since the word was first coined in 1942, rising out of occupational therapy offered to returning war veterans from World War 2. I have also described earlier the pioneering work of Peter Slade coining the phrase 'dramatherapy' in $195^{8}$ and his impact on the profession. I have also argued that dramatherapy specifically in the UK has come out of the pioneering drama work done both in schools and hospitals by the two of the founding members of the profession Sue Jennings and Billy Lindkvist (Holmwood, 2014). I have argued that there is an intrinsic link between the educational development of children with specific needs and the dramathrapy profession, something that sadly I feel is often forgotten in the jockeying for role and recognition of the various professions and bodies that

4 I was one of the last generation in the mid 1980's to receive a fully free Higher Education.

5 https://www.hesa.ac.uk/data-and-analysis/publications/destinations-2016-17 Accessed 29.11.20). 
support them, be they drama teachers, dramatherapists or drama based arts in health practitioners.

Despite all of this there has been a steady increase in the arts therapies, arts therapies training programmes and governance of these professions since the 1970's. More recent interest in the arts and health movement has been fuelled by the release of the UK Governments' Arts Health and Wellbeing Report $(2017)^{6}$ and the further consolidation of research in the field as described by Daykin in 'Arts, Health and Well-Being: A Critical Perspective on Research, Policy and Practice,' (2019), in which she describes the burgeoning of the international movement of arts in health and wellbeing over the last 20 years.

The University of Derby shares a unique position in the development of both Arts in Health and Arts Therapies programmes in the UK. Its Creative Expressive Arts Health and Wellbeing 7 undergraduate degree has existed for almost 30 years (Taylor \& Holmwood, 2019). Its early development was influenced by the Creative Expressive model developed by Jennings (1992). The undergraduate programme offers students a unique approach to studying in an arts and health frameworks using art, drama, music, and dance from an applied and developmental perspective. Though little known, the programme has been at the forefront of applied arts with its unique practical approaches to using the arts.

The University has since developed a full spectrum of post graduate arts therapies programmes to complement this, Art, Music, Dance and Dramatherapy. It is not coincidental that the book describing this (Taylor \& Holmwood, 2019) sets out its educational pedagogy by dividing the book into three sections using Van Gennep's (1960) pre-liminal, liminal and post-liminal 'Rites of Passage' charting student progression. A rite of passage in a western context relates to a major change in someone's life: birth, death or marriage for example. In a similar way this echoes the shifts students need to make from beginning an undergraduate degree to qualifying or moving onto post graduate or doctoral degrees, which is an integral part of their overall personal as well as educational development. The book features chapters on pedagogical approaches from current and past students and staff. It shares an emphasis on the 'wholeness' of the students' journey, acknowledging the physical, mental, social and spiritual development of the student, and balancing this with a range of practical and theoretical module assessments which have been a mainstay of the undergraduate programmes since its outset. This notion of wholeness echoes

6 https://www.gov.uk/government/publications/arts-for-health-and-wellbeing-an-evaluationframework Accessed 27.10.20.

7 Formerly called Creative Expressive Therapies until 2019. 
Dewey's concept of progressive education. The programme's focus on the concept of Deep Learning (Biggs \& Tang, 2011), that learning is never about learning facts but is about synthesising complex ideas at a deep level for the individual, which takes time. Additionally,'Threshold Concepts' (Myer \& Land, 2003) come into play. The ideas that until new knowledge is fully understood and synthesised at a deep level it remains 'troublesome' and 'challenging'. It could be argued that this is not too dissimilar to integral approaches to education

\section{$4 \quad$ Integral Education}

According to Ryan integral education within higher education has no specific definition. (2010). He goes on to chart a range of practitioners who have impacted upon integral education, describing it as having several elements including, being a form of 'emotional education' (2010, p. 51). He agrees with Zulaski (2017) that integral education can be charted back to the beginning of the 2oth Century. Both authors agree that two of the founders of integral education were Sri Aurobindo (1872-1950), who founded integral yoga and \& Mirra Alfassa, (1878-1973) known as the 'The Mother' both from India. Additionally Ma \& Subbiondo (this volume) (also discuss the importance of the Confucian scholar Wang Yang Ming (Ching, 1976) from a Chinese perspective as being highly influential.

Zulaski (2017) describes a very open and fluid approach to integral education that has the potential to acknowledge and accept a range of possible perspectives and theoretical ideas such as experiential and transformative learning. Zulaski has a strong emphasis on what might be described as a 'tacit' (felt) or embodied, attuned approach to education (Bennett, 2019), echoing Ryan's idea of it being an 'emotional education'. Something that is very familiar to anyone training within the arts and performing arts and especially those training within the arts therapies fields; this notion of an embodied and physical attunement is relevant in art making and particularly relevant to drama, dance movement and music therapists who use their bodies as a way of processing emotion and thought, both their own and those of the clients they work with.

Zulaski goes onto define 5 principals originally described by 'The Mother' as being 'complete integral education' (italics original) (2017, p. 22). The five elements being - physical, vital, mind, psychic and spiritual; A form of education that covers and integrates mind, body and spirit. Jorge et al (2010) describe this in a very similar manner by stating that integral education is 'participatory ... in which all human dimensions - body, vital, heart, mind and consciousness - are invited to co-creatively participate in the unfolding of learning and 
inquiry' (2010, p. 79). All of this is a far cry from traditional nineteenth century approaches to education being a form of 'rote learning' where the external facts are internalised and regurgitated, as necessary by students in order to pass an exam. Higher Education has for many years battled against these basic assumptions that students have brought to higher education from their earlier childhood school-based experiences where passing tests is essential in order to learn. For students coming with this experience it can be perceived as a struggle to make this pedagogical shift (Tozer, 2019), to something we might see as being more akin to Integral Education.

Influences Connections and Similarities between Integral Drama Based Pedagogy and Dramatherapy Training

It could be argued that integral education is akin or at least shares similarities to western perspectives of progressive education in that there is a move away from traditional teaching methods of rote learning and a greater acknowledgment of internal process and 'deep learning' (Biggs and Tang, 2011) for the student. I have also outlined some similarities between IDBP and the historical development of drama education. We shall now consider specific connections between ID BP and UK based dramatherapy training.

Ma and Subbiondo describe IDвP as taking place over 32 meetings and that sessions are structured into four parts 'mindfulness and meditation, warm-up and play, process drama, and discussion and sharing' (p. 599 this volume). This broad framework shares some similarity to educational drama in the UK (Holmwood, 2014), in that there is some expectation on individuals to make greater personal connections to a lesser or greater degree within the context of the dramatic work itself. Process drama having been used in more progressive forms of drama education for many decades. In other words, by students placing themselves into the shoes of the protagonist in the drama they can decide how they might respond or act in that situation with a greater connectedness than by merely observing from the outside. This is like Heathcote and her 'Mantel of the Expert' (O'Neil, 2015).

IDBP is aimed at those involved in teacher education, however it appears to have a greater emphasis on personal self-reflection which might go beyond the expectations of educational or even process drama. However, Ma and Subbiondo themselves state that: "IDвP differs from traditional educational drama courses that tend to be weak in the therapeutic function as well as differs from drama therapy and psychological drama courses that have greater focus on healing people with serious mental health problems" (p. 507 this volume). 
They therefore describe it as hybrid between an educational drama class and dramatherapy. They might describe it as a form of 'therapeutic drama'. This is not completely dissimilar to the Creative Expressive Arts Health \& Wellbeing undergraduate course at the University of Derby (Taylor \& Holmwood, 2019); where students are not trained to be creative arts therapists, but as arts practitioners are attuned to the therapeutic aspects of their art form in a wider general context and consider how to facilitate this within creative expressive groups. As part of their training, they are required to be involved in some aspect of self-reflection and personal processing. I would argue that aspects of IDBP have an even greater connections to the professional training of arts therapists, and dramatherapy specifically.

I have already discussed this pedagogical shift for students at undergraduate level when entering into a more uncertain world, where there are no certainties or right or wrong answer in a higher education context. I think this is amplified even further at post graduate master's level. Particularly where dramatherapy students are learning about their new discipline, about the techniques and approaches they will be using in order to work with clients. Just as importantly they will be learning about self through supervisory reflection and receiving personal therapy (usually) outside of the course. It is this incongruence of educational and therapeutic approaches and personal insight through therapy that impacts on the students experience and shapes their educational relationship with peers, tutors, and the wider training institution. Which is what Jackson describes as an 'ecological' perspective on learning to practice (2019). This is particularly pertinent when students discover hitherto unexcepted, repressed or forgotten experiences that bubble up to confabulate them in their developing practice and studies, where they are, ironically assessed as being good enough, or on occasions not good enough to qualify. In order to qualify they have to be seen to adhere to the HCPC code of professional conduct. ${ }^{8}$ It is this practice of dramatherapy training that I argue is most closely aligned to IDBP.

There have been relatively few articles written about the nature of the training of dramatherapists. According to Butler 'research on therapist education has indicated that therapists who are more aware of their own emotional experience are better equipped to work with the emotional experiences of their clients' (2017, p. 28). He goes onto say that 'within training programs, educators create opportunities to use the students' lived experience, both in-the-moment as well as historical, in order to foster a greater amount of emotional awareness' $(2017$, p. 28). Student dramatherapists are therefore within the context of their training using the artform of drama as a pedagogical tool to

8 https://www.hcpc-uk.org/standards/ (Accessed 3.12.20). 
develop the pre-requisite skills of the professional therapist but also framing this within their own personal experiences, which in themselves are also pedagogical. Ma and Subbiondo state that 'ID BP provides students with a safe space for self-development, empowering them to touch the unreal and divided parts of the ego ...' (p. 506 this volume). Their students also share a similar goal as the training is principally orientated towards the development of professional drama educators.

Butler goes onto state that because dramatherapy training is "experiential learning, [it is] often accompanied by these expectations, [and] can lead to a strong emotional response. These strong responses then lead to consequences both within and outside of the program" (2017, p. 29). There was an expectation in Butler's research that students should be "expected to have an emotional personal experience in class" (2017, p. 30). The consequences of these personal revelations or experiences were not in Butler's research shown to be completely benign, as students were in training, and any response had the potential to impact both peer and student/tutor relationships and impact on their overall education within the wider institution.

Ma and Subbiondo share similar considerations. For example, their use of a poem by Mary Oliver within IDBP. They state when using the poem in sessions with students it has a profound impact in that:

The "Journey" tells a story of you in the second person narrative. You is experiencing a fierce psychological conflict and struggle. On the one hand, it is the external distracting noise of you's life; and on the other hand, it is the inner voice of you that is overwhelmed (p. 510 this volume)

Students are encouraged to reflect and connect with the you within the poem. Both the poem and its development and the wider programme appears to have profound impact on the students' as Ma and Subbiondo state:

"When the meaning of the words of "The Journey" are interpreted by the students' embodied movements, the tension in the poem is amplified, lively and vivid. This becomes most apparent when following their performances of the freeze frames, the students sit in a circle and share their feelings. They tend to use words such as "shock," "determination," "hope," "growth," "fun," and "cooperation." They note that rehearsal and performance bring out one or more of the following related reactions: overwhelmed, restrained, hopeful and believing" (p. $5^{12}$ this volume). 
Butler argues that 'An academic setting greatly magnifies the intersection of education and therapy as the drive for good grades and advancement are an inherent aspect of most educational institutions' (2017, p. 33). These tensions are expressed by one student who said: 'I would say in terms of my personal process, the events that happened on the course ... had infinitely more a profound impact on my personal process than my therapy, what had taken place in my therapy. But what took place in my therapy was needed to support all the events that took place here' (2017, p. 33). Although the course in itself is not therapy and the personal therapy is conducted elsewhere outside of the training, it's the impact of the pedagogical and the personal in the training programme that appears to have the most impact. This appears to align closely with the training offered to professional educators in IDBP and the wider views of integral education "The integral world view and integral thinking are in truth two sides of the same coin...The method of integral thinking represents a dynamic integration of the scientific, phenomenological and dialectical methods of the West and the self-analytical, psycho-integrative, non-dual values of the East" (Chaudhuri, 1977, p. 85).

These two examples therefore appear to suggest that there is much connection between the challenges of the professional dramatherapist in training and the further training of drama educators within IDBP. However as highlighted in my own research, considering the similarity in the fields of drama education and dramatherapy I concluded that 'these spaces are influenced by both the contexts and discourses that surround them, making them nebulous and shifting' (Holmwood, 2014, p. 139), this connection is not simple, not only 'nebulous and shifting' but at times messy.

\section{Progressivism and Integralism}

This article has shown that what we might describe as 'progressive' approaches to education in a liberal west have some similarities and synergy to integral education as depicted from an Eastern Confucian perspective. The West does show a small, but significant, development of progressive drama education leading to the more embodied approaches, whilst China and the East has developed ideas from both India and China from the work of Wang Yang-Ming Sri Aurobindo (1995) and Mirra Alfassa.

However, this notion of 'progressive' and 'integral' have much greater overall connection, and the two cases I have used here of IDBP and dramatherapy training begin this dialogue. The linking of this notion of an 'embodied' 
approach, the idea of feelings connecting to cognitive thought is central to this debate. Good therapy is educational. Good education is therapeutic, even if not, intentionally, therapy. The notion that learning comes not from an external source that is imbued but starts from within when the student reaches out to make rational connections through relationships with ideas, fellow students and teachers, in order to make sense of their own internal process. To dwell on it, make sense of it, share it with others, theoretically, practically, spiritually, emotionally, and then return it transformed to self. Truly deep learning. This could be used to describe both integral and progressive educational approaches, and ironically good therapy too.

If we go back to one of the founding figures of integral education Zulaksi (2017) state's the Mothers five elements of integral education are physical, vital, mind, psychic and spiritual. Both case studies discussed above would appear to have the potential to fit within these five elements to a lesser or greater degree. Whereas some such ideas as 'spiritual,' in the West at least, might be a more difficult language, due to a Western history of the separation of state and religion; the spiritual in this case refers to the individual connecting with 'self' in a deeper more embodied and emotional sense. Emotions are not without rational thought or intellect; they should and do co-exist. Therefore, there is a liminal 'nebulous and shifting' (Holmwood, 2014, p. 139) place in which the body and mind connect with each other, we could call this liminal place 'education', be it progressive or integral.

\section{References}

Aurobindo, S. (1995) Secret of the Veda. Twin Lakes, Wisconsin: Lotus Press.

All Party Parliamentary Group on Arts Health \& Wellbeing Inquiry Report (2017) Creative Health: The Arts for Health \& Wellbeing. London: UK Government.

Bennett, J. (2019) "Attunement in Creativity \& Learning" in , J. Taylor and, C. Holmwood

(Eds) Learning as A Creative \& Developmental Process in Higher Education - A

Therapeutic Arts Approach and its Wider Application. London: Routledge.

Biggs, J. \& Tang, C. (2011) Teaching for Quality Learning at University (4th Ed). Maidenhead: Open University Press.

Bolton, G. (1988) Drama as Education-An Argument for Placing Drama at The Centre of the Curriculum. London: Longman.

Butler, J. (2017) The Complex Intersection of Education and Therapy in the Drama Therapy Classroom in The Arts in Psychotherapy, 53. DOI: 10.1016/j.aip.2017.01.010 Chaudhuri, H. (1977) The Evolution of Integral Conciousness. Wheaton, Illinois: The Theosophical Publishing House. 
Ching, Julia, ed. (1976) To Acquire Wisdom: The Way of Wang Yang-Ming. New York: Columbia University Press.

Cook, C. (1917) The Play Way. London: William Heineman Ltd.

Dakyn, N. (2019) Arts, Health and Well-Being: A Critical Perspective on Research, Policy and Practice. London: Routledge.

Dewey, J. (1938) Art as Experience. Carbondale, Illinois: Southern Illinois University Press.

Dewey, J. (1938) Experience and Education. New York: Macmillan.

Esbjorn-Hargens, S. Reams, J. Gunnlaugson, O. Eds (2010) Integral Education: New Directions for Higher Learning. New York: SUNY, SUNY Series in Integral Theory

Hogan (2001) Healing Arts: The history of art therapy. London: JKP.

Holmwood, C. (2014) Drama Education and Dramatherapy: Exploring the space between disciplines. London: Routledge.

Holmwood, C. (2015) "Dramatherapy, Tai Chi and Embodiment" in Creative Arts Creative Arts in Education and Therapy," (2015), 1: 63-75. Quotus Publishing.

Howlett, J. (2014) Progressive Education A Critical Introduction. London: Bloomsbury.

Jackson, N. (2019) "Ecological Perspectives on Learning to Practice in the Arts in Health and Arts in Therapies Fields, 183 to 204 in Taylor, J. \& Holmwood, C. (2019) (Eds) Learning as A Creative \& Developmental Process in Higher Education - A Therapeutic Arts Approach and its Wider Application. London: Routledge.

Jennings, S. (1984) Creative Therapy. London: Kemble Press.

Jennings, S. (1992) Dramatherapy with Families Groups and individuals: Waiting in the Wings. London: J KP.

Lindkvist, B. (1998) Bring White Beads When Calling on the Healer. USA: Rivendell House.

Ma, L. \& Subbiondo, J.L. (2022) "Integral Drama Based Pedagogy as a Model of Integral Education, The Journey of Personal Transformation" in this volume.

Meyer, J. Land, R. (2003) Threshold Concepts and Troublesome Knowledge Linkages to ways of practicing within the disciplines ETL Project Occasional Report 4. Edinburgh: Teaching and Learning Research Project (TLRP).

O’Neil, C. Johnson, L. (1984) (Eds) Dorothy Heathcote Collected Writings on Education and Drama. UK: Hutchinson

O'Neil, C. (2015) Dorothy Heathcote on Education and Drama. London: Routledge.

Peters, M. (2019) "10o Years of Dewey in China, 1919-1921 - A Reassessment," Beijing International Review of Education 1, 9-26.

Ryan, J. (2010) "The Complete Yoga, The Lineage of Integral Education," in EsbjornHargens, S., Reams, J., Gunnlaugson, O. Integral Education - New Directions for Higher Learning. New York: SUNY.

Slade, P. (1940) The Value of Drama in Religion, Education and Therapy. London: Guild of Pastoral Psychology, Guild Lecture No 8 22nd May 1940. 
Slade, P. (1954) Child Drama. London: University of London Press.

Slade, P (1958) "Dramatherapy as an Aid to Becoming a Person London: Guild of Pastoral Psychology," Guild Lecture No 103, September,1958.

Slade, P. (1995) Child Play - Its importance for human development. London: JKP.

Taylor, J. \& Holmwood, C. (2019) (Eds) Learning as A Creative \& Developmental Process in Higher Education - A Therapeutic Arts Approach and its Wider Application. London: Routledge.

Tozer K. (2019) “Re-thinking uncertainty in higher education using Klein's concept of the paranoid-schizoid and depressive positions "in Taylor, J. \& Holmwood, C. (Eds) Learning as A Creative \& Developmental Process in Higher Education - A Therapeutic Arts Approach and its Wider Application. London: Routledge. Pp. 33-45.

Van Gennep, A. (1960) Rites of Passage. Chicago: University of Chicago Press.

Zulaski, J. (2017) "A Complete Integral Education: Five Principal Aspects" in Integral Review $13,1$. 